Article

\title{
Environmental Tipping Points for Sperm Motility, Fertilization, and Embryonic Development in the Crown-of-Thorns Starfish
}

\author{
Ciemon Frank Caballes ${ }^{1, *}$, Morgan S. Pratchett ${ }^{1}$, Maia L. Raymundo ${ }^{2}$ \\ and Jairo A. Rivera-Posada ${ }^{3}$ \\ 1 ARC Centre of Excellence for Coral Reef Studies, James Cook University, Townsville, QLD 4811, Australia; \\ morgan.pratchett@jcu.edu.au \\ 2 School of Biological Sciences, University of Queensland, Brisbane, QLD 4072, Australia; \\ maia.raymundo@uqconnect.edu.au \\ 3 Academic Environmental Corporation, Universidad de Antioquia, Medellín, Antioquia 050010, Colombia; \\ jriveraposada@yahoo.com.au \\ * Correspondence: ciemon.caballes@my.jcu.edu.au; Tel.: +61-4-4781-5747
}

Academic Editors: Sven Uthicke and Michael Wink

Received: 30 November 2016; Accepted: 10 February 2017; Published: 15 February 2017

\begin{abstract}
For broadcast spawning invertebrates such as the crown-of-thorns starfish, early life history stages (from spawning to settlement) may be exposed to a wide range of environmental conditions, and could have a major bearing on reproductive success and population replenishment. Arrested development in response to multiple environmental stressors at the earliest stages can be used to define lower and upper limits for normal development. Here, we compared sperm swimming speeds and proportion of motile sperm and rates of fertilization and early development under a range of environmental variables (temperature: $20-36{ }^{\circ} \mathrm{C}$, salinity: $20-34 \mathrm{psu}$, and $\mathrm{pH}$ : 7.4-8.2) to identify environmental tipping points and thresholds for reproductive success. We also tested the effects of water-soluble compounds, derived from eggs, on sperm activity. Our results demonstrate that gametes, fertilization, and embryonic development are robust to a wide range of temperature, salinity, and $\mathrm{pH}$ levels that are outside the range found at the geographical limits of adult distribution and can tolerate environmental conditions that exceed expected anomalies as a result of climate change. Water-soluble compounds derived from eggs also enhanced sperm activity, particularly in environmental conditions where sperm motility was initially limited. These findings suggest that fertilization and embryonic development of crown-of-thorns starfish are tolerant to a wide range of environmental conditions, though environmental constraints on recruitment success may occur at later ontogenic stages.
\end{abstract}

Keywords: cleavage; gastrulation; sperm activity; temperature; salinity; $\mathrm{pH}$; Acanthaster outbreaks

\section{Introduction}

Outbreaks of the coral-eating crown-of-thorns starfish (CoTS), Acanthaster spp., are one of the most significant biological threats to coral reefs and account for a substantial proportion of coral mortality in the Indo-Pacific region [1-3]. CoTS are predisposed to major population fluctuations, whereby local densities may vary by several orders of magnitude [4], due to inherent features of their reproductive biology and behavior [5,6]. Reproductive success is central to explaining periodic increases in local densities [7]. Understanding the critical events in the early life history of CoTS is key to identifying population bottlenecks that could be strategically targeted to improve control programs and mitigate coral mortality [8]. Despite this, environmental drivers of variation in reproductive success for Acanthaster spp. remain poorly understood. 
Achieving high fertilization rates is vital in ensuring reproductive success [9]. Fertilization had initially been thought to be non-limiting, given that broadcast spawners, such as CoTS, release copious amounts of gametes during spawning [6,10]. Population replenishment in CoTS is believed to be largely regulated by larval provisioning, larval delivery, post-settlement competition and predation [11-14]. However, a host of factors, at the gamete, individual, and population levels, as well as prevailing environmental conditions, can influence fertilization success [9]. For example, changes in sperm swimming speeds and the proportion of motile sperm affect fertilization success in CoTS [15] and other echinoderms [16,17]. Previous studies have shown that the number and distribution of individuals and the prevailing flow conditions during spawning dictate the local concentration of gametes [18-20]. Fertilization rates of CoTS have been reported to reach up to $83 \%$ at the peak of a major spawning event [21]. In induced spawning experiments in the field, fertilization rates can be as high as $95 \%$ when male and female starfish are in very close proximity [20]. As expected, fertilization rates drop significantly as the distance between spawning individuals increases. Nevertheless, $70 \%$ fertilization success was still achieved at distances of up to $8 \mathrm{~m}$ between spawning individuals and more than $20 \%$ at a distance of $60 \mathrm{~m}$ [20]. Fertilization success per unit distance in CoTS is higher compared to other asteroid species and significantly greater than those reported for other marine invertebrates [7]. Despite achieving high fertilization rates at given sperm concentrations, at greater distances, and at longer durations from the point of gamete release [22], very little is known on the tolerance of gametes, fertilization, and early development of CoTS to a wide range of environmental conditions.

For broadcast spawning invertebrates such as CoTS, early life history stages occur in the water column where environmental factors could disrupt the initial phases in the process of population replenishment. The persistence and success of populations require that all developmental stages be completed successfully and the variable sensitivity of planktonic stages (i.e., gametes, fertilization, and early development) to environmental stressors (e.g., temperature, salinity, and $\mathrm{pH}$ ) may be a potential population bottleneck $[23,24]$. Evaluating the effects of environmental stress on gametes and early life history stages is important as this can result in detrimental flow-on effects where physiological performance and cellular responses of subsequent ontogeny depend on the success of preceding stages [23]. In addition, marine organisms are exposed not only to natural environmental stressors, but also the compounding effects of anthropogenic stressors, notably increasing global temperatures, pulses of decreased salinity brought about by higher frequency of cyclones and freshwater runoff, and reduced $\mathrm{pH}$ [24]. Climate change causes changes in baseline environmental conditions, such that inherent fluctuations of temperature, salinity, and $\mathrm{pH}$, particularly in nearshore waters, may increasingly exceed tolerance thresholds, especially for populations currently living at physiological limits [25].

Recent studies on the response of early life history stages of marine invertebrates to ocean warming and acidification, have improved our knowledge on environmental thresholds of several species [24]. Generally, temperature affects everything an organism does through its pervasive physiological impact on all biological functions [26]. Ocean acidification has negative impacts on development due to direct $\mathrm{pH}$ effects and hypercapnic suppression of metabolism, and is a major threat to marine calcifiers because acidification decreases carbonate saturation with a negative impact on skeleton formation [23,27]. Pulses of reduced salinity brought by heavy rainfall or freshwater lenses of river plumes have been reported to result in decreased growth and reproduction rates in some invertebrates [28] and affect the cellular osmoregulation in gametes and embryos [29]. The responses of echinoderms to these environmental stressors are stage- and species-specific, but gametes and fertilization appear to be robust to a wide range of temperature, salinity, and $\mathrm{pH}$ levels [30-32]. Environmental tolerances of echinoderm embryos are generally narrower than for gametes and fertilization $[16,31,33]$.

Spermatozoa of free-spawning marine organisms remain immobile at the time of gamete release but become motile spontaneously upon dilution in seawater. Evaluating the response of spermatozoa to environmental factors is important since activation is influenced by seawater temperature, osmotic 
pressure, extracellular $\mathrm{pH}$, ultraviolet radiation, and the concentration of specific ions relative to that in the seminal plasma in echinoderms [34-37]. Sperm swimming speeds in the polychaete Galeolaria caespitosa have been reported to be enhanced under increased water temperatures [38], but comparable research is yet to be undertaken for most echinoderms [23,27]. Decreased motility and inactivation of sperm at low salinities has also been reported in sea urchins [29,39]. Previous studies on echinoids also show reductions in the percentage of motile sperm at decreased $\mathrm{pH}$ and ultimately reproductive success [18-20]. There is also evidence that oocytes from conspecifics release attractants that induce chemotaxis toward the egg [40-42]. In some marine invertebrates, chemoattractants may not only change the direction of sperm swimming but also increase sperm swimming speeds and the proportion of motile sperm [43-45]. The interactive or additive effects of environmental stressors and egg-derived chemoattractants warrant further attention, especially given potential impacts of climate change on fertilization success.

The purpose of this study is to compare sperm behavior and rates of fertilization, as well as early development under a range of environmental variables to identify environmental tipping points and thresholds for reproductive success. As fertilization immediately follows spawning, existing environmental conditions during gamete release could potentially limit fertilization rates and early development even when sperm-to-egg ratios are optimal, which is expected when spawning individuals are aggregated, gamete release is synchronized, and flow conditions are low to moderate [7]. Here, we examine temperature, salinity, and $\mathrm{pH}$ thresholds of sperm motility, fertilization, cleavage, and gastrulation. Reproductive failure in echinoderms has been reported at different levels of these environmental parameters, but few have looked whether this is due to the sensitivity of gametes, failure of fertilization, or failure of fertilized eggs to cleave or hatch [46,47]. We also tested the excitatory effect of water-soluble egg extracts on sperm behavior to add a maternal dimension to the characterization of sperm motility. Sperm swimming speeds and proportion of motile sperm are discussed in relation to fertilization rates. Previous studies on the impacts of these environmental variables on marine invertebrates have mostly set experimental conditions with respect to projections by the Intergovernmental Panel on Climate Change [48] for temperature rise $\left(2{ }^{\circ} \mathrm{C}\right.$ to $4{ }^{\circ} \mathrm{C}$ above ambient), pulses of decreased salinity (regionally variable), and ocean acidification (0.2 to $0.4 \mathrm{pH}$ units below ambient) [49]. Here, we included extreme environmental stressor treatments to determine how far gametes, fertilization, and early development can be pushed to identify tipping points and thresholds for deleterious effects. Developmental arrest in response to multiple environmental stressors at the earliest stages can be used to define lower and upper limits for normal development. Quantifying environmental regulation of initial elements of reproductive success is important in understanding the spatial and temporal dynamics of populations of Acanthaster spp., as well as understanding vulnerability to environmental changes.

\section{Materials and Methods}

\subsection{Collection and Maintenance of Animals for Experiments}

Adult individuals of the Pacific species of crown-of-thorns starfish (Acanthaster cf. solaris) were collected from aggregations in reefs around Puntan Dos Amantes $\left(13^{\circ} 32.346^{\prime} \mathrm{N}, 144^{\circ} 48.200^{\prime} \mathrm{E}\right)$ on the northwest coast of the island of Guam, Micronesia in October 2013. Starfish were immediately transported to the University of Guam Marine Laboratory and allowed to acclimatize to ambient conditions for $48 \mathrm{~h}\left(28.79 \pm 0.23{ }^{\circ} \mathrm{C} ; 34.19 \pm 0.04 \mathrm{psu}\right.$; $\left.\mathrm{pH} 8.23 \pm 0.02\right)$ in 1000-L concrete tanks with flow-through seawater. Individuals were sexed by drawing contents from gonads along the arm junction using a syringe with a large-bore biopsy needle [7]. Male and female CoTS were placed in separate tanks prior to experiments. Gametes from gravid individuals were examined under a compound microscope to generally assess reproductive maturity of oocytes and sperm motility. 


\subsection{Preparation of Experimental Seawater}

\subsubsection{Water-Soluble Egg Extracts}

Water-soluble egg extracts and seawater solutions (ESW) were prepared by incubation of unfertilized eggs from five females (standardized to $100 \mathrm{egg} \cdot \mathrm{mL}^{-1}$ ) for $60-90 \mathrm{~min}[43,45]$ under different levels of temperature, salinity, or $\mathrm{pH}$ as described below. Eggs were filtered through a $0.22-\mu \mathrm{m}$ syringe filter (Millipore, Darmstadt, Germany) and immediately used in experiments. Filtered seawater $(0.2-\mu \mathrm{m})$ was used as controls and incubated under different levels of environmental treatments. Experimental seawaters were kept in sealed Nalgene ${ }^{\circledR}$ glass containers prior to experiments.

\subsubsection{Temperature}

Preliminary pilot studies have shown that temperature below $20^{\circ} \mathrm{C}$ resulted in zero fertilization and cleavage. Temperatures ranging from $20^{\circ} \mathrm{C}$ to $36^{\circ} \mathrm{C}$, at $2{ }^{\circ} \mathrm{C}$ intervals, were tested in this study. This experiment was done inside a temperature-controlled room set at $16^{\circ} \mathrm{C}$. Parafilm ${ }^{\circledR}$-sealed beakers with $0.2-\mu \mathrm{m}$ filtered seawater were placed in water baths with aquarium heaters (Eheim Jäger, Deizisau, Germany) connected to digital controllers (Aqua Logic Inc., San Diego, CA, USA) to maintain set temperatures. Pre-calibrated digital thermometers were placed in each water bath to monitor and stabilize set temperatures.

\subsubsection{Salinity}

Initial rangefinder experiments showed zero fertilization at $18 \mathrm{psu}$. Eight salinity levels were tested in this study: 20, 22, 24, 26, 28, 30,32, and 34 psu. Salinity treatments below ambient conditions ( $<34 \mathrm{psu}$ ) were prepared by adding distilled freshwater to $0.2-\mu \mathrm{m}$ filtered seawater until set levels were reached. This experiment was done in an incubator (VWR International, Radnor, PA, USA) set at $28^{\circ} \mathrm{C}$. Beakers were fitted with plastic lids that had a 12-rpm synchronous motor attached to a plastic stirrer to maintain set conditions and prevent the formation of artificial haloclines within beakers. Salinity of seawater samples from experimental beakers was also measured before and after experiments using HI 96822 Seawater Refractometer (Hanna Instruments, Woonsocket, RI, USA) with automatic temperature compensation.

\subsection{4. $\mathrm{pH}$}

This experiment was conducted to test the tolerance of fertilization and embryonic development in CoTS to different $\mathrm{pH}_{\mathrm{NIST}}$ levels: 7.4, 7.6, 7.8, 8.0, and 8.2. Experimental seawater $\mathrm{pH}$ levels (below ambient $\mathrm{pH}$ 8.2) was achieved by gently bubbling $\mathrm{CO}_{2}$ into reservoir overhead tanks, using a $\mathrm{pH}$ computer (Aqua-Medic of North America, CO, USA) connected to a solenoid valve, until programmed levels were reached. Experimental $0.2-\mu \mathrm{m}$ filtered seawater was gravity-fed to containers with $45-\mathrm{mm}$ mesh windows enclosed by a plastic jacket placed in water baths set at $28{ }^{\circ} \mathrm{C}$. Seawater $\mathrm{pH}$ in experimental containers were measured before and after experiments using Orion 3-Star benchtop pH meter (Thermo Scientific, MA, USA), which was triple calibrated with NIST-certified buffers ( $\mathrm{pH} 4.01$, $7.00,10.01)$.

\subsection{Sperm Speed and Motility}

Sperm speed (sperm point-to-point velocity $=$ total distance travelled per second) and sperm motility (percentage of motile sperm) were measured from five male starfish, using techniques described for crown-of-thorns starfish [15] and sea urchins [17]. Experimental seawater treatments were prepared as described in the previous section. For each dilution, $2 \mu \mathrm{L}$ of dry sperm were diluted with $4 \mathrm{~mL}$ of experimental seawater. One drop $(\sim 100 \mu \mathrm{L})$ of this sperm suspension was placed on an albumin-coated microscope slide and a coverslip, which were separated by a $0.75 \mathrm{~mm}$ thick O-ring and focus set midplane to minimize wall effects on sperm swimming speed [16]. Sperm behavior 
was captured using a Canon EOS 60D single lens reflex camera coupled with a Zeiss Axio Scope A1 (A-Plan ph1 10×/0.25 objective). The video camera was remotely controlled using Canon EOS Utility and set to take 25 frames per second over a two second period. All recordings were made within $10 \mathrm{~s}$ of the sperm suspension being placed on the slide. For each male, three replicate observations (slides) were made for three independent sperm dilutions under each temperature, salinity, or $\mathrm{pH}$ level and water-soluble egg extract treatment combination. Video recordings were post-processed with Sony Vegas Movie Studio HD (Sony Creative Software Inc., Middleton, WI, USA), and 1-s video clips from each slide (replicate) were analyzed using computer-assisted sperm analysis (CASA) plugin in Image J [50]. From an average of 200 sperm tracks analyzed per slide, mean sperm speed and percentage of motile sperm was determined for each replicate (slide) and standard deviation (SD) was calculated.

\subsection{Bioassays for Fertilization and Embryonic Development}

Three sets of experiments were conducted to quantify fertilization, cleavage, and gastrulation rates in response to different levels of (1) temperature, (2) salinity, and (3) $\mathrm{pH}$. Ripe ovary lobes were dissected from two female starfish and gently placed in glass dishes with $0.2-\mu \mathrm{m}$ filtered seawater (FSW) at $28^{\circ} \mathrm{C}$, to which, 1-methyladenine (1-MA) as added at a final concentration of $1 \times 10^{-4} \mathrm{M}$. Eggs were spawned after $60 \mathrm{~min}$ and pooled by transferring to a large glass beaker with FSW. For each experiment, eggs were split into triplicate containers (with 150-mL experimental seawater) for each treatment level. Approximately 300 eggs were rinsed with experimental seawater and transferred to beakers so that final density was $\sim 2$ eggs $\mathrm{mL}^{-1}$. Testes lobes were dissected from three male starfish and sperm that were shed after $\sim 3$ min were pooled together and placed in experimental seawater for $\sim 10 \mathrm{~s}$ at a concentration of $1 \times 10^{4}$ sperm mL $\mathrm{mL}^{-1}$ to ensure appropriate treatment conditions when added to containers with eggs. There was no water movement in the beaker at this point to minimize immotile sperm from artificially coming in contact with eggs. After $30 \mathrm{~min}$, eggs were rinsed three times in experimental FSW to remove excess sperm and resuspended in experimental FSW. Gametes were pooled to reflect a population of spawners, as might occur in nature, and to record the mean response of the system under investigation. Gamete concentrations used in this study resulted in high fertilization rates $(>95 \%)$ during procedural control experiments and none of the eggs showed fertilization envelopes without the addition of sperm, demonstrating that there was no contamination during the preparation and handling of gametes. After two hours, 100 eggs from each replicate were placed in a scintillation vial and $7 \%$ formalin was added to prevent further development. Fertilization (presence of fertilization envelope, Figure 1a) and/or holoblastic radial cleavage (cell division, Figure $1 b$ ) were assessed in the first 50 eggs seen across a gridded slide viewed under a compound microscope at low power. Beakers containing the remaining embryos were then resealed and maintained in experimental temperature, salinity, or $\mathrm{pH}$ conditions. After $24 \mathrm{~h}, 50$ embryos were scored as either "gastrula" if they had developed archenteron, or "non-gastrula", where invagination had not occurred (Figure 1c). Five independent runs using different sets of gamete sources were undertaken with full replication for each treatment. Mean values from three containers within runs were used as replicates in each experiment $(n=5)$ and SD calculated. Temperature, salinity, and temperature-compensated $\mathrm{pH}$ measurements of seawater in experimental beakers were monitored using a HI 9828 multiparameter handheld probe (Hanna Instruments, RI, USA), with only minimal fluctuation from set values $(<0.1)$. 
(a)

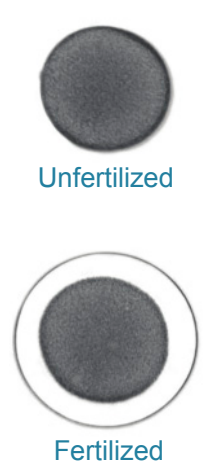

(b)

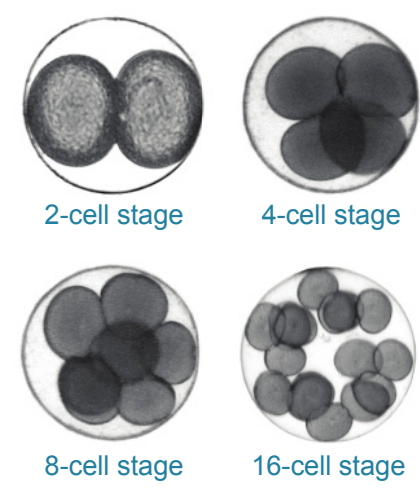

(c)

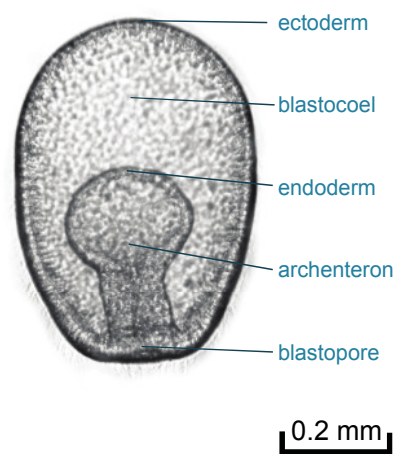

Figure 1. Early life history processes or stages assessed in this study: (a) fertilization; (b) early cleavage; and (c) gastrulation.

\subsection{Statistical Analyses}

Statistical comparisons of sperm speed between combinations of environmental treatment (temperature, salinity, or $\mathrm{pH}$ ) and water-soluble egg extracts was performed using a two-factor analysis of variance (ANOVA) followed by post hoc pairwise comparisons using the "lsmeans" function in $\mathrm{R}$ with Tukey's adjustment [51]. No significant departures from normality and homogeneity of variance were detected for all data. A generalized linear model (GLM) with binomial errors and logit link function was used to analyse the effect of each environmental treatment and water-soluble egg extracts (fixed categorical predictors) on the proportion of motile sperm. Significant overall tests were followed by post hoc pairwise comparisons between different levels of temperature, salinity, or $\mathrm{pH}$ with corrected $p$-values [52] using the "glht" function from the "multcomp" package in R [53]. Mean sperm speed and motility for each male $(n=5)$ across 3 replicate dilutions (slides) were used in these analyses.

A generalized linear model (GLM) with binomial errors and logit link function was used to analyse the effect of temperature, salinity, or $\mathrm{pH}$ (categorical predictors) on fertilization, cleavage, or gastrulation rates (binomial response variables). Quasibinomial error distributions were used in place of binomial errors to correct for overdispersion when detected [54]. This was followed by post hoc multiple comparisons with corrected $p$-values [52] using the "glht" function from the "multcomp" package in R [53]. Data from within treatments that had zero variance were excluded in the analyses.

\section{Results}

\subsection{Temperature}

Seawater temperature $\left(F_{8,72}=85.96, p<0.0001\right)$ and exposure to water-soluble egg extracts $\left(F_{1,72}=13.16, p=0.0005\right)$ had a significant effect on sperm swimming speeds in CoTS (Table A1). Sperm velocity was lowest at the minimum temperature tested, $20^{\circ} \mathrm{C}$ (FSW: $100.75 \mu \mathrm{m} \cdot \mathrm{s}^{-1} \pm 9.48 \mathrm{SD}$, here and in all instances hereafter; ESW: $127.05 \pm 14.40 \mu \mathrm{m} \cdot \mathrm{s}^{-1}$ ), and peaked at a temperature range of $28{ }^{\circ} \mathrm{C}$ to $34{ }^{\circ} \mathrm{C}$ (FSW: $>221 \mu \mathrm{m} \cdot \mathrm{s}^{-1}$; ESW: $>225 \mu \mathrm{m} \cdot \mathrm{s}^{-1}$ ) before slightly dropping back to $219 \pm 96 \mu \mathrm{m} \cdot \mathrm{s}^{-1}$ (FSW) and $228.01 \pm 25.59 \mu \mathrm{m} \cdot \mathrm{s}^{-1}$ (ESW) at $36{ }^{\circ} \mathrm{C}$ (Figure 2a). Sperm exposed to water-soluble egg extracts had consistently faster swimming speeds compared to controls, but this difference was most prominent between $20{ }^{\circ} \mathrm{C}$ and $26{ }^{\circ} \mathrm{C}$ where sperms swimming speeds were relatively slow in controls (Figure 2a). We found a significant variation in sperm motility between temperature treatment levels $\left(\chi^{2}=1233.07, d f=8, p<0.0001\right)$ and between control and water-soluble egg extract treatments $\left(\chi^{2}=31.34, d f=1, p=0.0008\right)$. The proportion of motile sperm was steadily increasing from a minimum of $8.80 \% \pm 3.02 \%$ (FSW) and $21.47 \% \pm 7.49 \%$ (ESW) at $20{ }^{\circ} \mathrm{C}$ then peaking at $>65 \%$ (FSW) and $>70 \%$ (ESW) for temperatures between $28^{\circ} \mathrm{C}$ and $34{ }^{\circ} \mathrm{C}$ (Figure $2 \mathrm{~b}$ ). 
Water temperature, ranging from 20 to $36^{\circ} \mathrm{C}$, had a significant effect on fertilization, cleavage and gastrulation for $A$ cf. solaris, whereby reproductive performance would be maximized at intermediate temperatures $\left(26-30{ }^{\circ} \mathrm{C}\right)$. For fertilization, there was significant variation across the full range of temperatures tested (Table A1; $\chi^{2}=1316.20, d f=8, p<0.0001$ ), mainly due to low fertilization under low and high temperature extremes. Fertilization rates were $>89 \%$ between $24{ }^{\circ} \mathrm{C}$ to $32{ }^{\circ} \mathrm{C}$ (Figure 2c). For cleavage, there was significant variation with temperature (Table A1; $\chi^{2}=521.09$, $d f=7, p<0.0001$ ). Cleavage was $>75 \%$ for $26{ }^{\circ} \mathrm{C}$ to $32{ }^{\circ} \mathrm{C}$ (Figure $2 \mathrm{~d}$ ), but greatly reduced at lower and higher temperatures. Temperature also had a significant effect on gastrulation rates (Table A1; $\left.\chi^{2}=822.66, d f=7, p<0.0001\right)$. The proportion of embryos undergoing gastrulation was maximized between $26^{\circ} \mathrm{C}$ and $32{ }^{\circ} \mathrm{C}$ (Figure 2e).
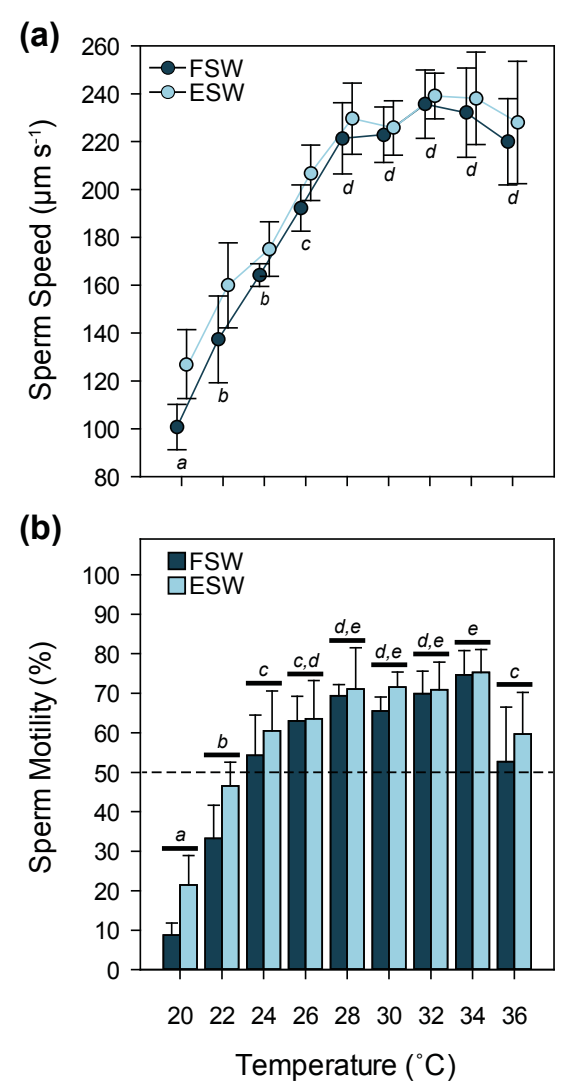
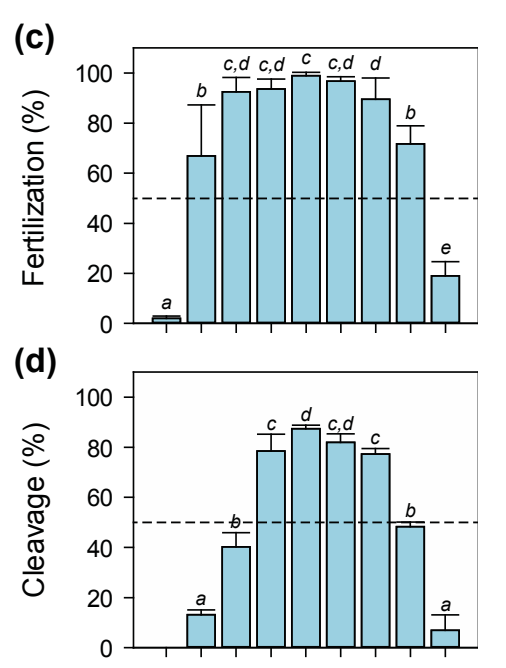

(e)

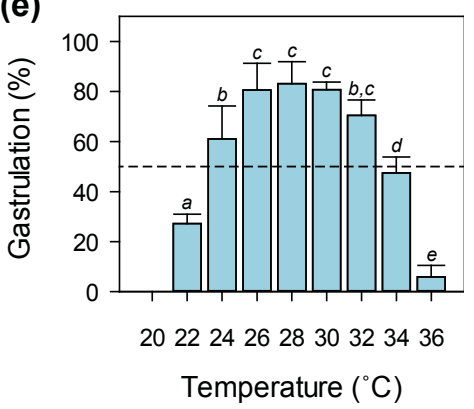

Figure 2. Thermal tolerance of sperm, fertilization, and embryonic development: (a) sperm speed (points slightly displaced for clarity); (b) sperm motility; (c) fertilization; (d) cleavage; and $($ e) gastrulation $(n=5)$. Letters next to error bar caps $( \pm \mathrm{SD})$ indicate significant differences based on post hoc pairwise comparisons with corrected $p$-values. FSW $=0.2-\mu \mathrm{m}$ filtered seawater (control); $\mathrm{ESW}=$ solution with water-soluble egg extract.

\subsection{Salinity}

Salinity $\left(F_{7,64}=5.83, p<0.0001\right)$ had a significant effect on sperm swimming speeds in CoTS (Table A1). The disparity in sperm velocity between treatments exposed to water-soluble egg extracts and controls was progressively wider from high to low salinity, but differences were not statistically significant $\left(F_{1,64}=2.93, p=0.0918\right)$ (Figure 3a). Variation between salinity treatments was mainly driven by differences between three groups: low sperm swimming speeds for treatments ranging from 20 to $22 \mathrm{psu}$, intermediate velocity at 24 and $26 \mathrm{psu}$, and significantly higher sperm velocity from 28 to 34 psu (Figure 3a). Sperm swimming speeds were relatively high across all treatments, with mean sperm velocity all above $170 \mu \mathrm{m} \cdot \mathrm{s}^{-1}$. Salinity $\left(\chi^{2}=523.43, d f=7, p<0.0001\right)$ also had a significant 
effect on sperm motility, but not water-soluble egg extracts $\left(\chi^{2}=16.42, d f=1, p=0.0682\right)$ (Table A1). The proportion of motile sperm was above $40 \%$ for salinities ranging from 24 to $34 \mathrm{psu}$.

Salinity had a significant effect on overall fertilization rates $\left(\chi^{2}=597.86, d f=7, p<0.0001\right)$. Fertilization envelopes did not form at salinities $<20 \mathrm{psu}$ in preliminary experiments, while $31.43 \% \pm 13.89 \%$ and $36.67 \% \pm 12.41 \%$ of eggs were fertilized in 20 psu and 22 psu treatments, respectively. Highest fertilization rates were achieved at $30 \mathrm{psu}(89.33 \% \pm 8.29 \%), 32$ psu $(97.60 \% \pm 2.34 \%)$, and $34 \mathrm{psu}(96.40 \% \pm 3.35 \%)$. The proportion of embryos undergoing cleavage was significantly different between salinity treatments (Table A1; $\chi^{2}=369.59, d f=5, p<0.0001$ ). Fertilized eggs did not cleave at 20 and $22 \mathrm{psu}$, while only $15.03 \% \pm 8.76 \%$ cleaved under the 24-psu treatment. Percentage of normal cleavage in CoTS was optimal $(>85 \%)$ when exposed to salinities ranging from $30-34$ psu. Cleavage rates at $26 \mathrm{psu}(57.04 \% \pm 14.64 \%)$ and $28 \mathrm{psu}(65.80 \% \pm 11.50 \%)$ treatments were significantly lower than those under 30-34 psu (Figure 3d). There was also a significant variation in the proportion of embryos undergoing gastrulation after $24 \mathrm{~h}$ between salinity treatments (Table A1; $\left.\chi^{2}=504.40, d f=5, p<0.0001\right)$. As with cleavage rates, no gastrulation occurred at 20 and $22 \mathrm{psu}$, and the proportion of embryos at gastrula stage was significantly higher at salinities between 30 and $34 \mathrm{psu}$ compared to $26 \mathrm{psu}(56.80 \% \pm 8.81 \%)$ and $28 \mathrm{psu}(65.20 \% \pm 10.07 \%)$ treatments, which were also significantly higher than $24 \mathrm{psu}$ treatment $(8.80 \% \pm 5.55 \%)$ (Figure $3 \mathrm{e})$.
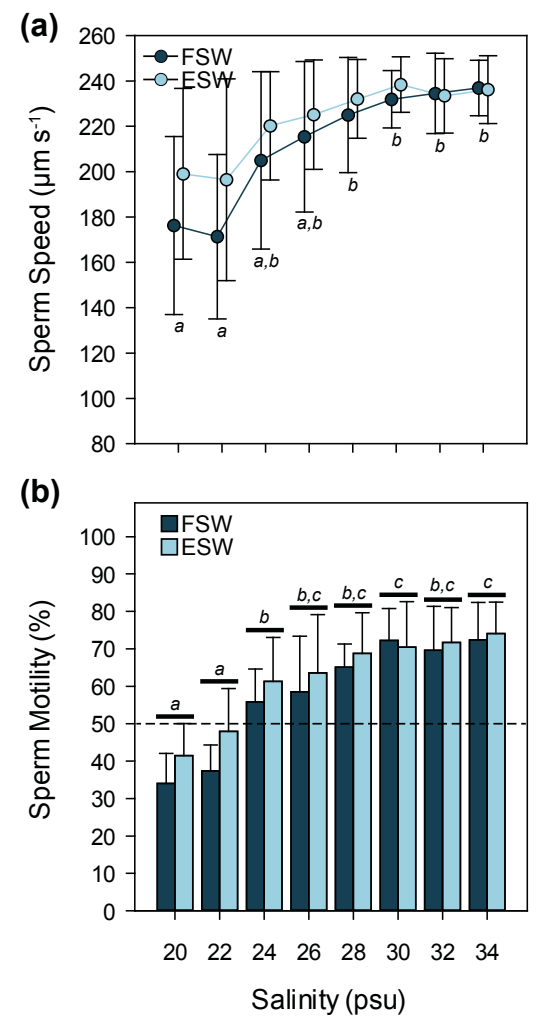
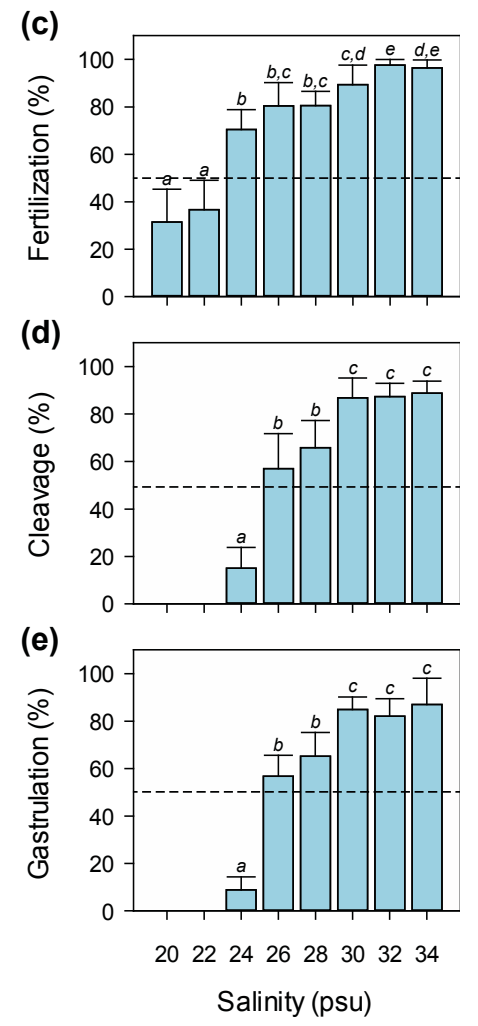

Figure 3. Effect of salinity on sperm behavior, fertilization, and early development: (a) sperm speed (points slightly displaced for clarity); (b) proportion of motile sperm, and proportion of eggs undergoing (c) fertilization; (d) cleavage; and (e) gastrulation $(n=5)$. Letters above error bars $( \pm$ SD) indicate significant differences based on post hoc pairwise comparisons with corrected $p$-values. FSW $=0.2-\mu \mathrm{m}$ filtered seawater (control); ESW = solution with water-soluble egg extract.

\section{3. $p H$}

Mean sperm swimming speeds differed significantly (Table A1) between $\mathrm{pH}$ treatments $\left(F_{4,40}=28.57, p<0.0001\right)$, but not between egg-derived extracts and controls $\left(F_{1,40}=3.85\right.$, $p=0.0568)$. For this experiment, sperm velocity was highest at $\mathrm{pH} 8.2\left(\mathrm{FSW}: 228.89 \pm 17.89 \mu \mathrm{m} \cdot \mathrm{s}^{-1}\right.$; 
ESW: $235.40 \pm 15.44 \mu \mathrm{m} \cdot \mathrm{s}^{-1}$ ) and $\mathrm{pH} 8.0$ treatments (FSW: $224.23 \pm 24.05 \mu \mathrm{m} \cdot \mathrm{s}^{-1}$; ESW: $222.23 \pm 27.65 \mu \mathrm{m} \cdot \mathrm{s}^{-1}$ ). Apart from $\mathrm{pH} 7.4$ treatments, where sperm velocity was lowest (FSW: $118.69 \pm 31.73 \mu \mathrm{m} \cdot \mathrm{s}^{-1}$; ESW: $\left.147.52 \pm 30.22 \mu \mathrm{m} \cdot \mathrm{s}^{-1}\right)$, sperm swimming speeds were relatively high $\left(>180 \mu \mathrm{m} \cdot \mathrm{s}^{-1}\right.$ ) for $\mathrm{pH}$ levels ranging from 7.6 to 8.2 (Figure 4a). We also found significant variations in the proportion of motile sperm under different $\mathrm{pH}\left(\chi^{2}=669.24, d f=4, p<0.0001\right)$ and egg extract $\left(\chi^{2}=38.11, d f=1, p=0.0033\right)$ treatments (Table A1). The proportion of motile sperm was consistently higher for treatments exposed to water-soluble egg extracts (Figure $4 \mathrm{~b}$ ). For sperm under $\mathrm{pH}$ levels ranging from 7.6 to 8.2 , motility was over $50 \%$, while the proportion of motile sperm was relatively low at pH 7.4 (FSW: $14.93 \% \pm 6.74 \%$; ESW: $29.87 \% \pm 13.50 \%$ ).

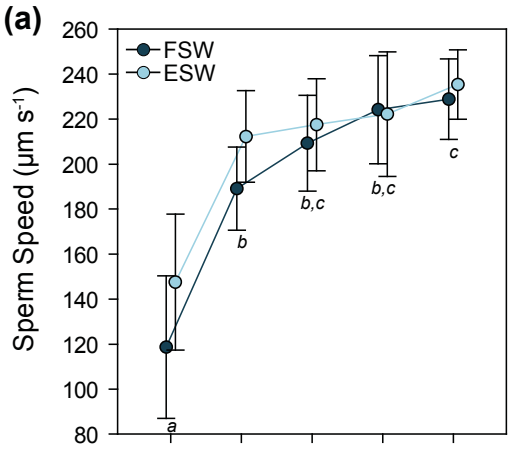

(b)

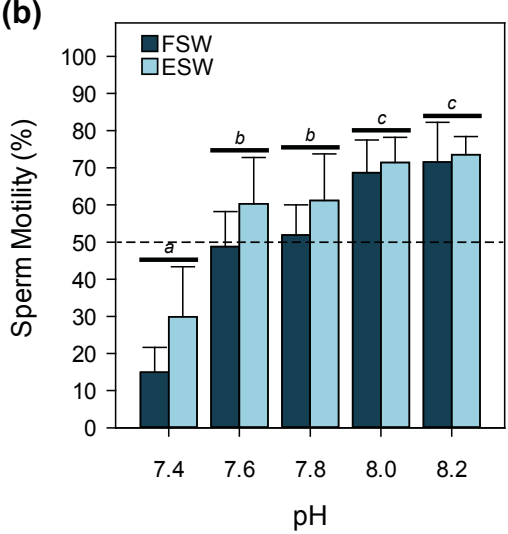

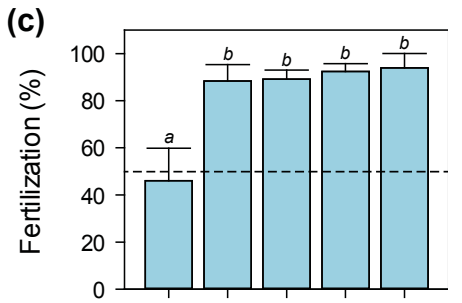

(d)

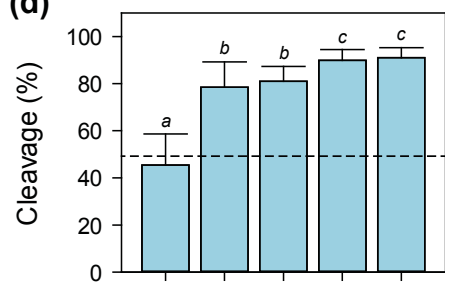

(e)

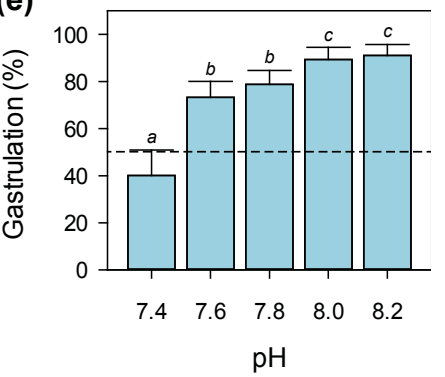

Figure 4. Influence of $\mathrm{pH}$ on sperm behavior, fertilization, and early development: (a) sperm speed (points slightly displaced for clarity); (b) proportion of motile sperm, and proportion of eggs undergoing (c) fertilization; (d) cleavage, and (e) gastrulation. Letters above error bars $( \pm S D)$ indicate significant differences based on post hoc pairwise comparisons with corrected $\mathrm{p}$-values. FSW $=0.2-\mu \mathrm{m}$ filtered seawater (control); ESW = solution with water-soluble egg extract.

Percentage of fertilization was high across all $\mathrm{pH}$ levels tested (Figure 4c), except for eggs in $\mathrm{pH} 7.4(46.09 \% \pm 13.73 \%)$, which was significantly lower than fertilization success at $\mathrm{pH} 7.6$ to $\mathrm{pH} 8.2$ (>88\%). The effect of low $\mathrm{pH}$ levels was more evident when looking at the frequency of normal cleavage (Figure $4 \mathrm{~d}$ ) and gastrulation (Figure $4 \mathrm{e})$. Cleavage $(45.48 \% \pm 13.17 \%)$ and gastrulation rate $(40.13 \% \pm 10.75 \%)$ at $\mathrm{pH} 7.4$ was lowest among all the $\mathrm{pH}$ levels tested. The range of $\mathrm{pH}$ levels for optimum normal cleavage and gastrulation $(>89 \%)$ was between $\mathrm{pH} 8.0$ and $\mathrm{pH} 8.2$. Proportion of embryos undergoing cleavage and gastrulation was significantly higher at optimum $\mathrm{pH}$ levels (8.0-8.2) compared to pH 7.6 and pH 7.8 (Table A1).

\section{Discussion}

This study shows that CoTS gametes, fertilization, and embryonic development are robust to a wide range of environmental conditions. Notably, these early life-stages could tolerate temperature, 
salinity, and $\mathrm{pH}$ conditions well beyond those experienced by Acanthaster spp. across their normal geographic range, even accounting for extreme anomalies in contemporary environmental conditions and predicted climate change impacts that are likely to occur at the end of this century [48]. If general to all populations, these findings have important implications for the reproductive success and dispersal of CoTS. A common pattern observed in this study was that sperm motility, fertilization, cleavage, and gastrulation were maximized at local summer temperature, salinity, and $\mathrm{pH}$ conditions, which generally coincides with periods of peak reproduction for CoTS [3,55] (Figure 5). This suggests that spawning in CoTS occurs at an optimal time when environmental conditions favor enhanced fertilization and early development. Our results also show that chemoattractants (water-soluble egg extracts) play some role in sperm activity across all environmental parameters tested.

(a)
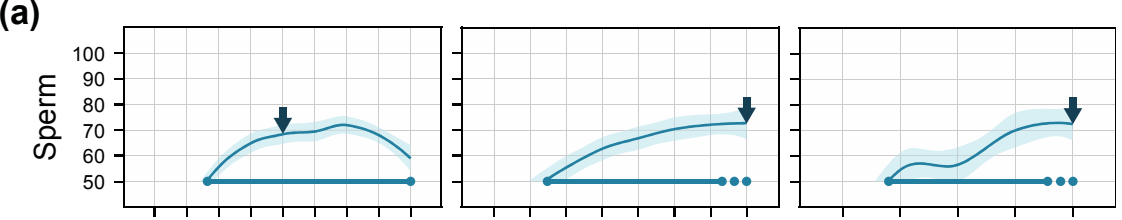

(b)
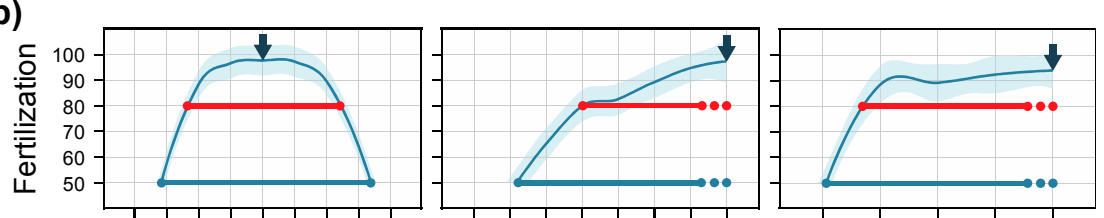

(c)
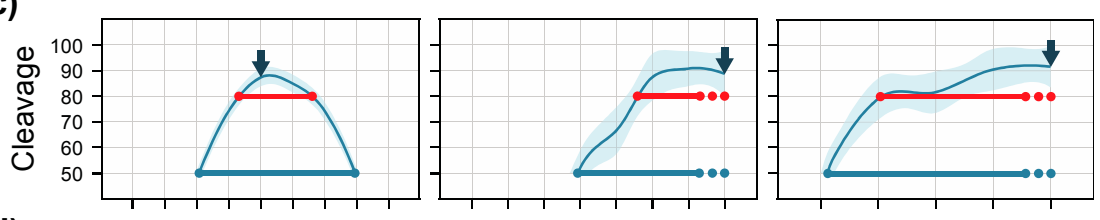

(d)
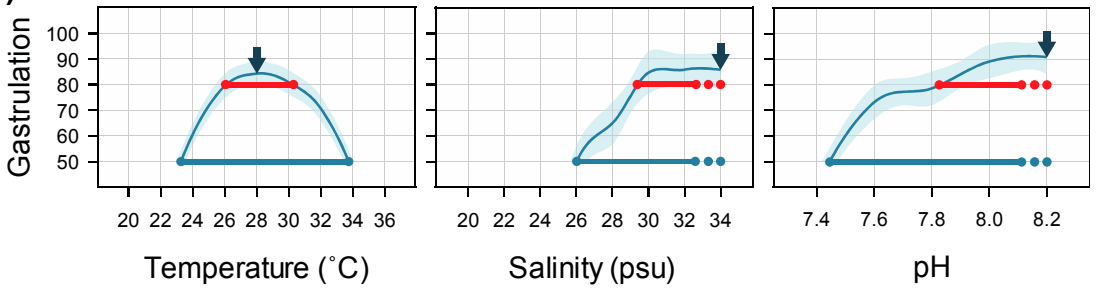

Figure 5. Environmental tipping points for: (a) sperm motility; (b) fertilization; (c) cleavage; and (d) gastrulation. Arrows signify mean ambient levels during spawning. Curves are loess smoothers fitted to dataset with proportions $>50 \%$; bold lines cover the range where: (a) proportion of motile sperm; (b) fertilization; (c) cleavage; and (d) gastrulation rates were $>50 \%$ (dark blue) or $>80 \%$ (red). Ellipses indicate that upper limits (above ambient) were not examined.

\subsection{Temperature}

Fertilization rates for CoTS were high $(>80 \%)$ over a wide temperature range $\left(24-32{ }^{\circ} \mathrm{C}\right)$, but do appear to be adversely affected by even higher temperatures $\left(34-36{ }^{\circ} \mathrm{C}\right)$, as shown for many other tropical echinoderms [30]. Thermal enhancement of fertilization as a result of increased motility and respiratory rates of spermatozoa, with concomitant decrease in ATP concentration, has been previously demonstrated in other echinoderms [56]. Thermal robustness of fertilization may be also due to the loading of protective maternal factors (e.g., heat shock proteins) during oogenesis [57,58]. This protection may be enhanced in species with large eggs-CoTS, for example, have larger eggs compared to other planktotrophic tropical asteroids and maternal provisioning to the egg influences early larval development [5]. Increased temperature and associated decrease in viscosity increases fertilization success due to increased sperm swimming speeds [38]. This was evident for high fertilization rates 
achieved at temperatures above ambient levels $\left(28^{\circ} \mathrm{C}\right)$ and low fertilization at lower temperature extremes (zero fertilization at $18{ }^{\circ} \mathrm{C}$ and below). However, reduced sperm activity at $22{ }^{\circ} \mathrm{C}$ and $24{ }^{\circ} \mathrm{C}$ still resulted in relatively high fertilization rates, while heightened sperm activity at $34{ }^{\circ} \mathrm{C}$ and $36{ }^{\circ} \mathrm{C}$ did not correspond with significant reductions in fertilization rates. The limiting factor appears to be the restriction placed on the viability of sperm subjected to temperature extremes [56]. At temperature extremes above normal, reduced fertilization was associated with increases in the incidence of polyspermy and granular fertilization membranes that adhere to the egg [59]. Increased sperm activity due to elevated temperature, as observed in this study, could also result in mechanical damage to the sperm and incur metabolic costs and exhaustion of energy reserves [29]. Physiological and viscosity-based aspects of high temperatures can influence sperm longevity, and hence fertilization success, by directly affecting sperm velocity [38].

Temperatures that do not restrict fertilization may nonetheless be detrimental for embryonic development [60]. Embryos of the temperate sea urchin, Strongylocentrotus purpuratus, subjected to seawater $8^{\circ} \mathrm{C}$ above ambient showed normal fertilization, but subsequently resulted in abnormal cleavage [61]. This was also consistent with earlier work by Rupp [30] where fertilization rates of CoTS decreased by $20 \%$ while cleavage fell by $60 \%$ at $34{ }^{\circ} \mathrm{C}$. Similarly, more recent work by Sparks et al. [62] showed that the proportion of cleaved embryos was significantly lower at $31^{\circ} \mathrm{C}$ compared to $27^{\circ} \mathrm{C}$ and $29^{\circ} \mathrm{C}$ treatments. Our study revealed that cleavage and gastrulation for CoTS were maximized over a relatively narrow temperature range $\left(26-32{ }^{\circ} \mathrm{C}\right)$ and closely reflects the range of temperatures to which CoTS are likely to be exposed throughout their geographic range [3]. Conversely, Habe et al. [63] showed that gastrulation was possible at a wider temperature range $\left(13-34{ }^{\circ} \mathrm{C}\right)$ than cleavage. This suggests that if post-gastrula embryos are swept into cooler waters, normal development can proceed during transport and will have important implications for long-range dispersal. However, the proportion of embryos that successfully cleave limits the proportion of embryos undergoing gastrulation. In this study, embryonic development in CoTS ceased at $20^{\circ} \mathrm{C}$ and below, which was slightly higher than the lower thermal limit for embryonic development reported for CoTS from the GBR, which was between 18 and $19{ }^{\circ} \mathrm{C}[33,64]$. This might reflect the less variable thermal environment of adult CoTS from Guam used in this study compared to CoTS from the GBR [3]. Thermal acclimatization of adults, particularly during gametogenesis, has been found to shift the thermotolerance of echinoderm embryos $[33,65]$.

\subsection{Salinity}

Out of the three pervasive environmental stressors investigated in this study, response to salinity is perhaps the least studied for CoTS. Here, we found that the lower salinity limit for successful fertilization ( $>50 \%$ ) in Acanthaster spp. was about $24 \mathrm{psu}$ (Figure 5). No fertilization occurred after $2 \mathrm{~h}$ at salinities below $20 \mathrm{psu}$. At 20 and $22 \mathrm{psu}$, less than $10 \%$ of eggs produced fertilization envelopes. This range and lower salinity limit appears to be common in asteroids (24 to $32 \mathrm{psu}$ in Asterias amurensis [31]; 22 to 34 psu in Asterina pectinifera [66]), echinoids (26 to $36 \mathrm{psu}$ in Echinocardium cordatum [67]; 24 to $32 \mathrm{psu}$ in Echinarachnius parma [47]), and holothuroids (24 to $32 \mathrm{psu}$ in Eupentacta fraudatrix [68]). Fertilization was highest at mean ambient salinity conditions experienced by adults in their natural habitat throughout most of the year. Dinnel et al. [39] found that fertilization of gametes of the sea urchin, Strongylocentrotus purpuratus, was best at the salinity at which the adults were held. Contrary to these observations, Roller and Stickle [69] found no evidence of acclimation of echinoid gametes when Lytechinus variegatus were exposed to different salinities prior to spawning.

Developmental failure at low salinity is often thought to reflect limited fertilization, possibly due to substantial reductions in sperm motility. There is a paucity of work on the response of echinoderm spermatozoa to salinity fluctuations and most examples come from research on sperm activity in commercially valuable teleost fishes $[44,70,71]$. Sperm swimming speeds and sperm motility were relatively high between 24 and 34 psu and decreased slightly at 20 and 22 psu, which partly mirrored the range observed for fertilization. Minor improvements in sperm activation when exposed to 
water-soluble egg extracts were observed, but were not significant. The influence of egg extracts on sperm velocity and motility was greater at lower salinities.

Although there was some fertilization at 20-22 psu, eggs failed to cleave at these salinities and less than $20 \%$ cleaved at $24 \mathrm{psu}$. The failure of eggs to develop at low salinity largely reflects an inability of fertilized eggs to complete meiosis and cleave, rather than simply an inability of eggs to become fertilized at these low salinities. Salinity changes appear to have most detrimental effects for ova, which are unable to control water flow in and out of the cell. Osmotic shock experiments on the spermatozoa and ova of the echinoid, Parechinus angulosus, prior to fertilization under optimal temperature and salinity conditions indicated that temperature gradients exerted a greater effect on spermatozoa while low salinity was more deleterious to ova-at salinities below $15 \mathrm{psu}$, water was imbibed by the ova, which swelled and lysed. Salinity tolerance of gastrulation mirrored that of cleavage. Salinity levels as low as 10 psu have been observed to persist in nearshore and mid-shelf waters in the GBR after flood events [72]. Since embryos were not as tolerant to low salinities as previously expected [63], the timing of reduced salinity events would be critical in predicting the population response.

\section{3. $p H$}

Our results show that fertilization in Acanthaster spp. was robust to reduced $\mathrm{pH}$. Patterns of fertilization success in relation to $\mathrm{pH}$ were coincident with relatively high sperm swimming speeds and proportion of motile sperm down to $0.6 \mathrm{pH}$ units below ambient $(\mathrm{pH} 8.2)$ and significant reductions at $\mathrm{pH} 7.4$ (Figure 5). In looking at the potential effects of near-future ocean acidification on CoTS recruitment, Uthicke et al. [15] found that low $\mathrm{pH}$ reduced sperm motility and velocity, which resulted in reduction of fertilization rates by $0.7 \%$ at $\mathrm{pH} 7.9$ and $25 \%$ at $\mathrm{pH} 7.7$ across a wide range of sperm concentrations. It was not clear whether impaired sperm motility, resulting in reduced fertilization at low $\mathrm{pH}$, may be due to acidosis or the narcotic effect of hypercapnia on sperm [73]. For the sea urchins Hemicentrotus pulcherrimus and Echinometra mathaei, seawater acidified by $\mathrm{CO}_{2}$ had a more severe effect on fertilization compared to $\mathrm{HCl}$-acidified seawater, suggesting that hypercapnia may be more influential to fertilization. However, cross-factorial experiments showed no significant difference in fertilization rates between different combinations of temperature and $\mathrm{pH}$ (7.6 to 8.1) treatments [74]. This is consistent with our findings wherein no significant differences in fertilizations rates were found for $\mathrm{pH}$ ranging from 7.6 to 8.2. The mechanism of hypercapnic stress on sperm involves the control intracellular $\mathrm{pH}$; although these effects may be overcome through respiratory dilution effects when sperm is released into the water column [75]. Coelomic fluid surrounding CoTS gonads has a mean $\mathrm{pH}$ of 7.49 [15], which is relatively low, hence may be activated when seawater $\mathrm{pH}$ levels are above this. This could explain the robustness of sperm motility and fertilization in CoTS even at relatively low $\mathrm{pH}$. In addition, our results also demonstrated that water-soluble compounds derived from eggs also promoted sperm motility at low $\mathrm{pH}$. Activation of nonmotile sperm by egg-derived compounds may provide a mechanism by which the energy reserves of sperm can be conserved in the absence of eggs, thereby maintaining sperm viability for extended periods [38,43]. This response has been reported for many species of corals, molluscs, echinoderms and ascidians [49].

The $\mathrm{pH}$ tolerance range for cleavage and gastrula embryos coincided with that of fertilization, albeit with slight reductions in frequency. Similarly, Kamya et al. [74] reported that $\mathrm{pH}$ had no significant effect on gastrulation in CoTS. Marine invertebrates that do not calcify during early developmental stages are generally robust to reduced $\mathrm{pH}[23,32]$. Later stages (bipinnaria and brachiolaria) in the life history of CoTS are more sensitive to reduced $\mathrm{pH}$ and have been shown to suffer high rates of larval abnormality and mortality at low $\mathrm{pH}[15,74]$.

\subsection{Interactive Effects and Implications for Subsequent Larval Development}

Our results show that absolute sperm velocity $\left(221-237 \mu \mathrm{m} \cdot \mathrm{s}^{-1}\right)$, at ambient temperature $\left(28^{\circ} \mathrm{C}\right)$, salinity (34 psu), and $\mathrm{pH}(8.2)$ levels, was slightly higher compared to previous estimates on CoTS sperm swimming speeds $\left(210 \mu \mathrm{m} \mathrm{s}^{-1}\right.$ [15]). These values are generally higher compared 
to estimates of sperm swimming speeds in other marine invertebrates, e.g., echinoids (Heliocidaris erythrogramma, 26-38 $\mu \mathrm{m} \cdot \mathrm{s}^{-1}$ [16,17]; L. variegatus, 153-275 $\mu \mathrm{m} \cdot \mathrm{s}^{-1}$ [76]), bivalves (Macoma calcarea, $\sim 60 \mu \mathrm{m} \cdot \mathrm{s}^{-1}$ [77]; Mytilus galloprovincialis, $\sim 50 \mu \mathrm{m} \cdot \mathrm{s}^{-1}$ [77]; Crassostrea gigas, $94 \mu \mathrm{m} \cdot \mathrm{s}^{-1}$ [78]), and polychaetes (G. caespitosa, 45-114 $\mu \mathrm{m} \cdot \mathrm{s}^{-1}[45,79]$ ). High sperm velocity over a wide range of temperature, salinity, and $\mathrm{pH}$ levels partly explains high fertilization rates of CoTS in the field [21]. However, there is a possible trade-off between sperm velocity and sperm longevity, which also influences fertilization success [76]. Sperm longevity was not quantified in this study, but previous studies have shown that CoTS sperm can also remain competent for longer periods relative to other echinoderm species, resulting in relatively higher fertilization rates at greater distances [22].

The response of gametes and early life history stages to multiple environmental stressors may have significant flow-on effects on the survival and development of subsequent larval stages, and thus, on successful recruitment. In the GBR, spawning of CoTS have usually coincided with peak summer temperatures, as well as high precipitation. Although fertilization and embryonic development may be robust to high temperatures (up to $34^{\circ} \mathrm{C}$ ), survival may be low when salinities drop (below $25 \mathrm{psu}$ ) during heavy rainfall events that result in high freshwater discharge from rivers. Disregarding the influence of other variables (i.e., predation, dispersal), the proportion of embryos progressing to subsequent larval stages will be substantially reduced. Tolerance of CoTS larvae has also been shown to be stage-specific and may constrain successful recruitment further [7]. Bipinnaria larvae of CoTS can to tolerate temperatures between 14.5 and $32{ }^{\circ} \mathrm{C}$ for up to $48 \mathrm{~h}$, while the brachiolaria stage is more sensitive to temperature variation [63]. In terms of tolerance to salinity, bipinnaria larvae can tolerate abrupt salinity changes down to 21 psu [63,80], while brachiolaria larvae rupture even with a decrease in salinity of $2 \mathrm{psu}$ [81]. High flow events have also been associated with elevated nutrient levels and phytoplankton densities, which have been shown to improve larval survival and development [12,82], even more so when modulated by increased temperatures up to $30^{\circ} \mathrm{C}$ [83].

Here we showed that $\mathrm{CO}_{2}$-acidified seawater (down to $\mathrm{pH}$ 7.6) did not have a significant effect on fertilization and early embryonic development. The detrimental effects of ocean acidification have been shown to be more apparent in subsequent larval stages. Uthicke et al. [15] found that normal development and settlement in CoTS larvae kept at $\mathrm{pH} 7.6$ was significantly reduced compared to $\mathrm{pH} 8.1$ treatments. Low $\mathrm{pH}(7.6)$ coupled with elevated temperatures $\left(30^{\circ} \mathrm{C}\right)$ also had an additive negative effect on larval size and development [74]. However, the positive effects of increased temperature on larval growth [83] may ameliorate the detrimental effects of low $\mathrm{pH}$.

\section{Conclusions}

Taken together, our results show that CoTS gametes, fertilization, and embryonic development are robust to a wide range of temperature, salinity, and $\mathrm{pH}$ levels, well beyond environmental conditions found within the current geographical distribution of Acanthaster spp. Majority of sperm are motile at temperatures between 24 and $36^{\circ} \mathrm{C}$, salinities between 24 and $34 \mathrm{psu}$, and pH between 7.6 and 8.2. Over $50 \%$ of eggs are fertilized at wide range of temperature (22-34), salinity (24-34), and $\mathrm{pH}(7.6-8.2)$ levels. The robustness of fertilization to these pervasive environmental stressors may be attributed to the molecular predisposition of CoTS sperm [84], which possesses an enhanced capacity for high fertilization rates, compared to other echinoderms [22]. Compared to fertilization, tolerance range for cleavage was mostly narrower for temperature $\left(26-32^{\circ} \mathrm{C}\right)$, salinity $(26-34 \mathrm{psu})$, and $\mathrm{pH}$ (7.6-8.2). Gastrulation under salinity and $\mathrm{pH}$ levels tested coincided with cleavage rates, while thermotolerance range for gastrulation was slightly wider than cleavage $\left(24-32{ }^{\circ} \mathrm{C}\right)$. In general, the effects of temperature and $\mathrm{pH}$ on fertilization and early development mostly corresponded with the sensitivity of sperm to these stressors, while response to salinity was largely due to detrimental effects on osmotic balance in eggs. Water-soluble compounds associated with eggs also enhanced sperm activity, particularly in environmental conditions where sperm motility was initially limited. Although the response to multiple environmental stressors was tested in this study, these pervasive environmental parameters impact marine organisms simultaneously. Future work should include 
cross-factorial studies to tease out additive, antagonistic, and synergistic interactions between these factors [24]. The tolerance of the earliest stages of development to a wide range of environmental stressors suggests that later ontogenic stages (larvae, juveniles, adults) may be more vulnerable to small fluctuations in environmental conditions.

Acknowledgments: The ARC Centre of Excellence for Coral Reef Studies provided funding for this study through a PhD research allocation to CFC and annual research appropriation to MSP. We are grateful to A.M. Kerr, L.J. Raymundo, R.G. Rowan, M. Kitamura, and M. Byrne for technical advice. We also thank J. Miller, J. Cummings, T. Reynolds, J. Gault and the staff at University of Guam Marine Laboratory for field and laboratory assistance. Comments from two anonymous reviewers have significantly improved this manuscript.

Author Contributions: C.F.C., M.S.P., and J.R.P. conceived and designed the experiments; C.F.C and M.L.R. performed the experiments; C.F.C. analyzed the data; M.S.P. and J.R.P. contributed reagents, materials, and analysis tools; and C.F.C., M.S.P., M.L.R., J.R.P. wrote the paper.

Conflicts of Interest: The authors declare no conflict of interest. The funder had no role in the design of the study; in the collection, analyses, or interpretation of data; in the writing of the manuscript, and in the decision to publish the results.

\section{Appendix A}

Table A1. Results of statistical analyses on the effects of temperature, salinity, and $\mathrm{pH}$ on sperm behavior, fertilization, and early development.

\begin{tabular}{|c|c|c|c|}
\hline Source & DF & Statistic $\left(\mathrm{F}, \chi^{2}\right)$ & $p$ \\
\hline \multicolumn{4}{|l|}{ Temperature } \\
\hline \multicolumn{4}{|l|}{ Sperm Speed ${ }^{1}$} \\
\hline temperature & 8 & 85.96 & $<0.0001$ \\
\hline egg extract & 1 & 13.16 & 0.0005 \\
\hline temperature $\times$ egg extract & 8 & 0.76 & 0.6353 \\
\hline \multicolumn{4}{|l|}{ Sperm Motility $^{2}$} \\
\hline temperature & 8 & 1233.07 & $<0.0001$ \\
\hline egg extract & 1 & 31.34 & 0.0008 \\
\hline temperature $\times$ egg extract & 8 & 32.79 & 0.1612 \\
\hline Fertilization ${ }^{2}$ & 8 & 1316.20 & $<0.0001$ \\
\hline Cleavage $^{2}$ & 7 & 521.09 & $<0.0001$ \\
\hline Gastrulation $^{2}$ & 7 & 632.82 & $<0.0001$ \\
\hline \multicolumn{4}{|l|}{ Salinity } \\
\hline \multicolumn{4}{|l|}{ Sperm Speed ${ }^{1}$} \\
\hline salinity & 7 & 5.83 & $<0.0001$ \\
\hline egg extract & 1 & 2.93 & 0.0918 \\
\hline salinity $\times$ egg extract & 7 & 0.31 & 0.9449 \\
\hline \multicolumn{4}{|l|}{ Sperm Motility 2} \\
\hline salinity & 7 & 525.43 & $<0.0001$ \\
\hline egg extract & 1 & 16.42 & 0.0682 \\
\hline salinity $\times$ egg extract & 7 & 9.62 & 0.9626 \\
\hline Fertilization 2 & 7 & 597.86 & $<0.0001$ \\
\hline Cleavage $^{2}$ & 5 & 369.59 & $<0.0001$ \\
\hline Gastrulation $^{2}$ & 5 & 504.40 & $<0.0001$ \\
\hline \multicolumn{4}{|l|}{ pH } \\
\hline \multicolumn{4}{|l|}{ Sperm Speed ${ }^{1}$} \\
\hline$p H$ & 4 & 28.57 & $<0.0001$ \\
\hline egg extract & 1 & 3.85 & 0.0568 \\
\hline$p H \times$ egg extract & 4 & 0.74 & 0.5706 \\
\hline \multicolumn{4}{|l|}{ Sperm Motility $^{2}$} \\
\hline$p H$ & 4 & 669.24 & $<0.0001$ \\
\hline egg extract & 1 & 38.11 & 0.0033 \\
\hline$p H \times$ egg extract & 4 & 18.05 & 0.3943 \\
\hline Fertilization $^{2}$ & 4 & 234.28 & $<0.0001$ \\
\hline Cleavage $^{2}$ & 4 & 95.37 & $<0.0001$ \\
\hline Gastrulation $^{2}$ & 4 & 213.24 & $<0.0001$ \\
\hline
\end{tabular}

\footnotetext{
${ }^{1}$ Two-way Analysis of Variance (ANOVA): $F$ value. ${ }^{2}$ Analysis of Deviance for generalized linear models (GLM):
} $\chi^{2}$ value. 


\section{References}

1. De'ath, G.; Fabricius, K.E.; Sweatman, H.P.A.; Puotinen, M. The 27-year decline of coral cover on the Great Barrier Reef and its causes. Proc. Natl. Acad. Sci. USA 2012, 109, 17995-17999. [CrossRef] [PubMed]

2. Baird, A.H.; Pratchett, M.S.; Hoey, A.S.; Herdiana, Y.; Campbell, S.J. Acanthaster planci is a major cause of coral mortality in Indonesia. Coral Reefs 2013, 32, 803-812. [CrossRef]

3. Pratchett, M.S.; Caballes, C.F.; Rivera-Posada, J.A.; Sweatman, H.P. Limits to understanding and managing outbreaks of crown-of-thorns starfish (Acanthaster spp.). Oceanogr. Mar. Biol. An Annu. Rev. 2014, 52, 133-200.

4. Uthicke, S.; Schaffelke, B.; Byrne, M. A boom-bust phylum? Ecological and evolutionary consequences of density variations in echinoderms. Ecol. Monogr. 2009, 79, 3-24. [CrossRef]

5. Caballes, C.F.; Pratchett, M.S.; Kerr, A.M.; Rivera-Posada, J.A. The role of maternal nutrition on oocyte size and quality, with respect to early larval development in the coral-eating starfish, Acanthaster planci. PLoS ONE 2016, 11, e0158007. [CrossRef] [PubMed]

6. Babcock, R.C.; Milton, D.A.; Pratchett, M.S. Relationships between size and reproductive output in the crown-of-thorns starfish. Mar. Biol. 2016, 163, 234. [CrossRef]

7. Caballes, C.F.; Pratchett, M.S. Reproductive biology and early life history of the crown-of-thorns starfish. In Echinoderms: Ecology, Habitats and Reproductive Biology; Whitmore, E., Ed.; Nova Science Publishers, Inc.: New York, NY, USA, 2014; pp. 101-146.

8. Hoey, J.; Campbell, M.; Hewitt, C.; Gould, B.; Bird, R. Acanthaster planci invasions: Applying biosecurity practices to manage a native boom and bust coral pest in Australia. Manag. Biol. Invasions 2016, 7, 213-220. [CrossRef]

9. Levitan, D.R. The ecology of fertilization in free-spawning invertebrates. In Ecology of Marine Invertebrate Larvae; McEdward, L.R., Ed.; CRC Press: Boca Raton, FL, USA, 1995; pp. 123-156.

10. Conand, C. Distribution, reproductive cycle and morphometric relationships of Acanthaster planci (Echinodermata: Asteroidea) in New Caledonia, western tropical Pacific. In Proceedings of the 5th International Echinoderm Conference, Galway, Ireland, 24-29 September 1985; pp. 499-506.

11. Yamaguchi, M. Recruitment of coral reef asteroids, with emphasis on Acanthaster planci (L.). Micronesica 1973, 9, 207-212.

12. Fabricius, K.E.; Okaji, K.; De'ath, G. Three lines of evidence to link outbreaks of the crown-of-thorns seastar Acanthaster planci to the release of larval food limitation. Coral Reefs 2010, 29, 593-605. [CrossRef]

13. Hock, K.; Wolff, N.H.; Condie, S.A.; Anthony, K.R.N.; Mumby, P.J. Connectivity networks reveal the risks of crown-of-thorns starfish outbreaks on the Great Barrier Reef. J. Appl. Ecol. 2014, 51, 1188-1196. [CrossRef]

14. Cowan, Z.L.; Dworjanyn, S.A.; Caballes, C.F.; Pratchett, M.S. Predation on crown-of-thorns starfish larvae by damselfishes. Coral Reefs 2016, 35, 1253-1262. [CrossRef]

15. Uthicke, S.; Pecorino, D.; Albright, R.; Negri, A.P.; Cantin, N.; Liddy, M.; Dworjanyn, S.A.; Kamya, P.Z.; Byrne, M.; Lamare, M.D. Impacts of ocean acidification on early life-history stages and settlement of the coral-eating sea star Acanthaster planci. PLoS ONE 2013, 8, e82938. [CrossRef] [PubMed]

16. Havenhand, J.N.; Buttler, F.R.; Thorndyke, M.C.; Williamson, J.E. Near-future levels of ocean acidification reduce fertilization success in a sea urchin. Curr. Biol. 2008, 18, 651-652. [CrossRef] [PubMed]

17. Schlegel, P.; Havenhand, J.N.; Gillings, M.R.; Williamson, J.E. Individual variability in reproductive success determines winners and losers under ocean acidification: A case study with sea urchins. PLoS ONE 2012, 7, e53118. [CrossRef] [PubMed]

18. Denny, M.W.; Shibata, M.F. Consequences of surf-zone turbulence for settlement and external fertilization. Am. Nat. 1989, 134, 859-889. [CrossRef]

19. Levitan, D.R.; Sewell, M.A.; Chia, F.-S. How distribution and abundance influence fertilization success in the sea urchin Strongylocentotus franciscanus. Ecology 1992, 73, 248-254. [CrossRef]

20. Babcock, R.C.; Mundy, C.N.; Whitehead, D. Sperm diffusion models and in situ confirmation of long-distance fertilization in the free-spawning asteroid Acanthaster planci. Biol. Bull. 1994, 186, 17-28. [CrossRef]

21. Babcock, R.C.; Mundy, C.N. Reproductive biology, spawning and field fertilization rates of Acanthaster planci. Mar. Freshw. Res. 1992, 43, 525-534. [CrossRef]

22. Benzie, J.A.H.; Dixon, P. The effects of sperm concentration, sperm: Egg ratio, and gamete age on fertilization success in crown-of-thorns starfish (Acanthaster planci) in the laboratory. Biol. Bull. 1994, 186, 139-152. [CrossRef] 
23. Byrne, M. Global change ecotoxicology: Identification of early life history bottlenecks in marine invertebrates, variable species responses and variable experimental approaches. Mar. Environ. Res. 2012, 76, 3-15. [CrossRef] [PubMed]

24. Przeslawski, R.; Byrne, M.; Mellin, C. A review and meta-analysis of the effects of multiple abiotic stressors on marine embryos and larvae. Glob. Chang. Biol. 2015, 21, 2122-2140. [CrossRef] [PubMed]

25. Helmuth, B.; Mieszkowska, N.; Moore, P.; Hawkins, S.J.; Hawkins, S.J. Living on the edge of two changing worlds: Forecasting the responses of rocky intertidal ecosystems to climate change. Annu. Rev. Ecol. Evol. Syst. 2006, 37. [CrossRef]

26. Hoegh-Guldberg, O.; Pearse, J.S. Temperature, food availability, and the development of marine invertebrate larvae. Am. Zool. 1995, 35, 415-425. [CrossRef]

27. Przeslawski, R.; Ahyong, S.; Byrne, M.; Wörheide, G.; Hutchings, P.A. Beyond corals and fish: The effects of climate change on noncoral benthic invertebrates of tropical reefs. Glob. Chang. Biol. 2008, 14, 2773-2795. [CrossRef]

28. Roberts, D.E.; Davis, A.R.; Cummins, S.P. Experimental manipulation of shade, silt, nutrients and salinity on the temperate reef sponge Cymbastela concentrica. Mar. Ecol. Prog. Ser. 2006, 307, 143-154. [CrossRef]

29. Greenwood, P.J.; Bennett, T. Some effects of temperature-salinity combinations on the early development of the sea urchin Parechinus angulosus (Leske). Fertilization. J. Exp. Mar. Biol. Ecol. 1981, 51, 119-131. [CrossRef]

30. Rupp, J.H. Effects of temperature on fertilization and early cleavage of some tropical echinoderms, with emphasis on Echinometra mathaei. Mar. Biol. 1973, 23, 183-189. [CrossRef]

31. Kashenko, S.D. Responses of embryos and larvae of the starfish Asterias amurensis to changes in temperature and salinity. Russ. J. Mar. Biol. 2005, 31, 294-302. [CrossRef]

32. Dupont, S.; Ortega-Martínez, O.; Thorndyke, M.C. Impact of near-future ocean acidification on echinoderms. Ecotoxicology 2010, 19, 449-462. [CrossRef] [PubMed]

33. Johnson, L.G.; Babcock, R.C. Temperature and the larval ecology of the crown-of-thorns starfish, Acanthaster planci. Biol. Bull. 1994, 187, 304-308. [CrossRef]

34. Mita, M.; Nakamura, M. Energy metabolism of sea urchin spermatozoa: An approach based on echinoid phylogeny. Zool. Sci. 1998, 15, 1-10. [CrossRef] [PubMed]

35. Shirai, H.; Ikegami, S.; Kanatani, H.; Mohri, H. Regulation of sperm motility in starfish. I. Initiation of movement. Dev. Growth Differ. 1982, 24, 419-428. [CrossRef]

36. Lu, X.Y.; Wu, R.S.S. Ultraviolet damages sperm mitochondrial function and membrane integrity in the sea urchin Anthocidaris crassispina. Ecotoxicol. Environ. Saf. 2005, 61, 53-59. [CrossRef] [PubMed]

37. Lu, X.Y.; Wu, R.S.S. UV induces reactive oxygen species, damages sperm, and impairs fertilisation in the sea urchin Anthocidaris crassispina. Mar. Biol. 2005, 148, 51-57. [CrossRef]

38. Kupriyanova, E.; Havenhand, J.N. Effects of temperature on sperm swimming behaviour, respiration and fertilization success in the serpulid polychaete, Galeolaria caespitosa (Annelida: Serpulidae). Invertebr. Reprod. Dev. 2005, 48, 7-17. [CrossRef]

39. Dinnel, P.A.; Link, J.M.; Stober, Q.J. Improved methodology for a sea urchin sperm cell bioassay for marine waters. Arch. Environ. Contam. Toxicol. 1987, 16, 23-32. [CrossRef] [PubMed]

40. Miller, R.L. Demonstration of sperm chemotaxis in Echinodermata: Asteroidea, Holothuroidea, Ophiuroidea. J. Exp. Zool. 1985, 234, 383-414.

41. Cook, S.P.; Brokaw, C.J.; Muller, C.H.; Babcock, D.F. Sperm chemotaxis: Egg peptides control cytosolic calcium to regulate flagellar responses. Dev. Biol. 1994, 165, 10-19. [CrossRef] [PubMed]

42. Nishigaki, T.; Chiba, K.; Miki, W.; Hoshi, M. Structure and function of asterosaps, sperm-activating peptides from the jelly coat of starfish eggs. Zygote 1996, 4, 237-245. [CrossRef] [PubMed]

43. Bolton, T.F.; Havenhand, J.N. Chemical mediation of sperm activity and longevity in the solitary ascidians Ciona intestinalis and Ascidiella aspersa. Biol. Bull. 1996, 190, 329-335. [CrossRef]

44. Litvak, M.K.; Trippel, E.A. Sperm motility patterns of Atlantic cod (Gadus morhua) in relation to salinity: Effects of ovarian fluid and egg presence. Can. J. Fish. Aquat. Sci. 1998, 55, 1871-1877. [CrossRef]

45. Kupriyanova, E.; Havenhand, J.N. Variation in sperm swimming behaviour and its effect on fertilization success in the serpulid polychaete Galeolaria caespitosa. Invertebr. Reprod. Dev. 2002, 41, 21-26. [CrossRef]

46. Byrne, M.; Ho, M.A.; Selvakumaraswamy, P.; Nguyen, H.D.; Dworjanyn, S.A.; Davis, A.R. Temperature, but not $\mathrm{pH}$, compromises sea urchin fertilization and early development under near-future climate change scenarios. Proc. R. Soc. B Biol. Sci. 2009, 276, 1883-1888. [CrossRef] [PubMed] 
47. Allen, J.D.; Pechenik, J.A. Understanding the effects of low salinity on fertilization success and early development in the sand dollar Echinarachnius parma. Biol. Bull. 2010, 218, 189-199. [CrossRef] [PubMed]

48. Intergovernmental Panel on Climate Change (IPCC). Climate Change 2014: Synthesis Report. Contribution of Working Groups I, II and III to the Fifth Assessment Report of the Intergovernmental Panel on Climate Change; IPCC: Geneva, Switzerland, 2014.

49. Byrne, M. Impact of ocean warming and ocean acidification on marine invertebrate life history stages: Vulnerabilities and potential for persistence in a changing ocean. Oceanogr. Mar. Biol. Annu. Rev. 2011, 49, $1-42$.

50. Wilson-Leedy, J.G.; Ingermann, R.L. Development of a novel CASA system based on open source software for characterization of zebrafish sperm motility parameters. Theriogenology 2007, 67, 661-672. [CrossRef] [PubMed]

51. R Development Core Team. R: A Language and Environment for Statistical Computing. R Foundation for Statistical Computing, Vienna, Austria. Available online: http://www.R-project.org/ (accessed on 31 May 2016).

52. Benjamini, Y.; Hochberg, Y. Controlling the false discovery rate: A practical and powerful approach to multiple testing. J. R. Stat. Soc. Ser. B 1995, 57, 289-300.

53. Hothorn, T.; Bretz, F.; Westfall, P. Simultaneous Inference in General Parametric Models. Biometrical J. 2008, 50, 346-363. [CrossRef] [PubMed]

54. Crawley, M.J. The R Book; John Wiley \& Sons Ltd.: Sussex, UK, 2013.

55. Cheney, D.P. Spawning and aggregation of Acanthaster planci in Micronesia. In Proceedings of the Second International Coral Reef Symposium; Great Barrier Reef Committee: Brisbane, Australia, 1974; Volume 1, pp. 591-594.

56. Mita, M.; Hino, A.; Yasumasu, I. Effect of temperature on interaction between eggs and spermatozoa of sea urchin. Biol. Bull. 1984, 166, 68-77. [CrossRef]

57. Yamada, K.; Mihashi, K. Temperature-independent period immediately after fertilization in sea urchin eggs. Biol. Bull. 1998, 195, 107-111. [CrossRef]

58. Hamdoun, A.; Epel, D. Embryo stability and vulnerability in an always changing world. Proc. Natl. Acad. Sci. USA 2007, 104, 1745-1750. [CrossRef] [PubMed]

59. Hagström, B.E.; Hagström, B. The effect of decreased and increased temperatures on fertilization. Exp. Cell Res. 1959, 16, 174-183. [CrossRef]

60. Andronikov, V.B. Heat resistance of gametes of marine invertebrates in relation to temperature conditions under which the species exist. Mar. Biol. 1975, 30. [CrossRef]

61. Farmanfarmaian, A.; Giese, A.C. Thermal tolerance and acclimation in the western purple sea urchin, Strongylocentrotus purpuratus. Physiol. Zool. 1963, 36, 237-243. [CrossRef]

62. Sparks, K.M.; Foo, S.A.; Uthicke, S.; Byrne, M.; Lamare, M.D. Paternal identity influences response of Acanthaster planci embryos to ocean acidification and warming. Coral Reefs 2017, 36, 325-338. [CrossRef]

63. Habe, T.; Sawamoto, S.; Ueno, S.; Kosaka, M.; Ogura, M. Studies on the Conservation and Management of Coral Reefs and the Control of Acanthaster Planci Juveniles; Report of Grant-in-Aid for Scientific Research; Ministry of Education, Science and Culture: Tokyo, Japan, 1989; pp. 158-186. (In Japanese)

64. Lamare, M.D.; Pecorino, D.; Hardy, N.; Liddy, M.; Byrne, M.; Uthicke, S. The thermal tolerance of crown-of-thorns (Acanthaster planci) embryos and bipinnaria larvae: Implications for spatial and temporal variation in adult populations. Coral Reefs 2014, 33, 207-219. [CrossRef]

65. Johnson, L.G.; Chenoweth, J.E.; Bingham, B.L. Population differences and thermal acclimation in temperature responses of developing sea urchin embryos. Proc. S. D. Acad. Sci. 1990, 69, 99-108.

66. Kashenko, S.D. The combined effect of temperature and salinity on development of the sea star Asterina pectinifera. Russ. J. Mar. Biol. 2006, 32, 37-44. [CrossRef]

67. Kashenko, S.D. Adaptive responses of embryos and larvae of the heart-shaped sea urchin Echinocardium cordatum to temperature and salinity changes. Russ. J. Mar. Biol. 2007, 33, 381-390. [CrossRef]

68. Kashenko, S.D. Combined effect of temperature and salinity on the development of the holothurian Eupentacta fraudatrix. Russ. J. Mar. Biol. 2000, 26, 188-193. [CrossRef]

69. Roller, R.A.; Stickle, W.B. Effects of temperature and salinity acclimation of adults on larval survival, physiology, and early development of Lytechinus variegatus (Echinodermata: Echinoidea). Mar. Biol. 1993, 116, 583-591. [CrossRef] 
70. Griffin, F.J.; Pillai, M.C.; Vines, C.A.; Kääriä, J.; Hibbard-Robbins, T.; Yanagimachi, R.; Cherr, G.N. Effects of salinity on sperm motility, fertilization, and development in the Pacific herring, Clupea pallasi. Biol. Bull. 1998, 194, 25-35. [CrossRef]

71. Elofsson, H.; Van Look, K.; Borg, B.; Mayer, I. Influence of salinity and ovarian fluid on sperm motility in the fifteen-spined stickleback. J. Fish Biol. 2003, 63, 1429-1438. [CrossRef]

72. Devlin, M.J.; DeBose, J.L.; Ajani, P.; Teixeira da Silva, E.; Petus, C.; Brodie, J.E. Phytoplankton in the Great Barrier Reef: Microscopy analysis of community structure in high flow events. In Report to the National Environmental Research Program; Reef and Rainforest Research Centre Limited: Cairns, Australia, 2013; p. 68.

73. Johnson, C.H.; Clapper, D.L.; Winkler, M.M.; Lee, H.C.; Epel, D. A volatile inhibitor immobilizes sea urchin sperm in semen by depressing the intracellular pH. Dev. Biol. 1983, 98, 493-501. [CrossRef]

74. Kamya, P.Z.; Dworjanyn, S.A.; Hardy, N.; Mos, B.; Uthicke, S.; Byrne, M. Larvae of the coral eating crown-of-thorns starfish, Acanthaster planci in a warmer-high $\mathrm{CO}_{2}$ ocean. Glob. Chang. Biol. 2014, 20, 3365-3376. [CrossRef] [PubMed]

75. Chia, F.-S.; Bickell, L.R. Echinodermata. In Reproductive Biology of Invertebrates, Volume 2; Adiyodi, K.G., Adiyodi, R.G., Eds.; New York, NY, USA, 1983; pp. 545-620.

76. Levitan, D.R. Sperm velocity and longevity trade off each other and infuence fertilization in the sea urchin Lytechinus variegatus. Proc. R. Soc. B Biol. Sci. 2000, 267, 531-534. [CrossRef] [PubMed]

77. Vihtakari, M.; Havenhand, J.N.; Renaud, P.E.; Hendriks, I.E. Variable individual- and population-level responses to ocean acidification. Front. Mar. Sci. 2016, 3, 51. [CrossRef]

78. Havenhand, J.N.; Schlegel, P. Near-future levels of ocean acidification do not affect sperm motility and fertilization kinetics in the oyster Crassostrea gigas. Biogeosciences 2009, 6, 3009-3015. [CrossRef]

79. Schlegel, P.; Havenhand, J.N.; Obadia, N.; Williamson, J.E. Sperm swimming in the polychaete Galeolaria caespitosa shows substantial inter-individual variability in response to future ocean acidification. Mar. Pollut. Bull. 2014, 78, 213-217. [CrossRef] [PubMed]

80. Henderson, J.A. Preliminary observations on the rearing and development of Acanthaster planci (L.) (Asteroidea) larvae. Fish. Notes Queensl. Dep. Harb. Mar. 1969, 3, 69-79.

81. Henderson, J.A.; Lucas, J.S. Larval development and metamorphosis of Acanthaster planci (Asteroidea). Nature 1971, 232, 655-657. [CrossRef] [PubMed]

82. Wolfe, K.; Graba-Landry, A.; Dworjanyn, S.A.; Byrne, M. Larval starvation to satiation: Influence of nutrient regime on the success of Acanthaster planci. PLOS ONE 2015, 10, e0122010. [CrossRef] [PubMed]

83. Uthicke, S.; Logan, M.; Liddy, M.; Francis, D.S.; Hardy, N.; Lamare, M.D. Climate change as an unexpected co-factor promoting coral eating seastar (Acanthaster planci) outbreaks. Sci. Rep. 2015, 5, 8402. [CrossRef] [PubMed]

84. Stewart, M.J.; Stewart, P.; Rivera-Posada, J.A. De novo assembly of the transcriptome of Acanthaster planci testes. Mol. Ecol. Resour. 2015, 15, 953-966. [CrossRef] [PubMed]

(C) 2017 by the authors; licensee MDPI, Basel, Switzerland. This article is an open access article distributed under the terms and conditions of the Creative Commons Attribution (CC BY) license (http://creativecommons.org/licenses/by/4.0/). 